\title{
Dinamika fertiliteta etničkih skupina u Hrvatskoj od 1998. do 2012.
}

DOI: $10.11567 /$ met.30.1.3

UDK: 314.33=054.57(497.5)"1998/2012" 314.33:323.1](497.5)"1998/2012"

Izvorni znanstveni rad Primljeno: 2.4.2014.

Prihvaćeno: 10.7.2014.

\section{Dario Pavić}

Odjel za sociologiju, Hrvatski studiji Sveučilišta u Zagrebu, Zagreb

dpavic@hrstud.hr

\begin{abstract}
SAŽETAK
Etničke skupine u pojedinim državama mogu imati različitu dinamiku fertiliteta od većinskoga naroda, ovisno o svome ekonomskom, društvenom i kulturnom statusu. Cilj istraživanja jest procijeniti promjenu opće stope fertiliteta i stope ukupnog fertiliteta etničkih skupina u Republici Hrvatskoj od 1998. do 2012. Broj fertilnih žena u analiziranom razdoblju procijenjen je linearnim modelom na temelju njihova broja iz 2001. i 2011., a podaci o rođenjima za svaku godinu bili su dostupni iz obrazaca DEM-1. Drugi je cilj usporediti razlike u općim stopama fertiliteta etničkih skupina u 2011. godini. Za tu analizu provedena je standardizacija stopa fertiliteta, gdje je populacija hrvatske narodnosti bila standardna. Provedeno je i razlaganje (dekompozicija) razlika općih stopa fertiliteta između Hrvata i nacionalnih manjina na komponente dobno specifičnih stopa fertiliteta i dobne strukture. Analiza vremenskog trenda stopa fertiliteta pokazala je da je rast stopa fertiliteta najvjerojatnije rezultat različitog načina popisivanja stanovnika 2001. i 2011., dok je stvarni trend pada fertiliteta utvrđen kod romske i albanske narodnosti zbog mijenjanja tradicionalnih uloga žena i općeg poboljšanja statusa žena u tim populacijama. Suvremene razlike $\mathrm{u}$ fertilitetu etničkih skupina uglavnom su rezultat razlika u dobno specifičnim stopama fertiliteta etničkih skupina, a manje razlika u dobnoj strukturi fertilnih kontingenata. Apsolutne razlike u općim stopama fertiliteta između narodnosti nisu prevelike i rezultat su prostorne, ekonomske i socijalne izoliranosti nacionalnih manjina.
\end{abstract}

KLJUČNE RIJEČI: narodnost, fertilitet, rođeni, Hrvatska, popis stanovništva

\section{UVOD}

Odrednice i dinamika fertiliteta pojedine populacije najčešće se povezuju s ekonomskom dinamikom i promjenama koje ona izaziva, no vrlo često sama ekonomska situacija ne može objasniti razlike u fertilitetu (Forste i Ti- 
enda, 1996). Bolje rečeno, ekonomske razlike, a posljedično i biološki sastav određenih skupina u populaciji rezultat su procesa koji pogađaju određene skupine na različit način. Jedan od prvih čimbenika za koji se utvrdilo da djeluje na opisani način jest narodnost, odnosno pripadnost određenoj etničkoj skupini. To je posebice značajno ako je etnička skupina ujedno i manjinska skupina u društvu zbog niza ekonomskih, društvenih, psiholoških, vjerskih i ostalih čimbenika koji je odvajaju od dominantnog naroda (Forste i Tienda, 1996).

Za potrebe ove analize bit će predstavljeni najznačajniji doprinosi istraživanja razlika u natalitetu i fertilitetu različitih etničkih skupina koji ujedno predstavljaju i teorijski okvir ovoga istraživanja (usp. Pavić, 2013). Razlike u fertilitetu etničkih skupina zabilježene su u zemljama razvijenog Zapada, prije svega u Velikoj Britaniji, SAD-u i Njemačkoj. Tako se u prvome desetljeću 21. stoljeća u Velikoj Britaniji smanjuje visoki fertilitet nacionalnih manjina, iako neke zadržavaju visoke stope fertiliteta (Coleman i Dubuc, 2010). U Sjedinjenim Američkim Državama visokoobrazovane žene bijele populacije (u izvorniku: whites) češće odgađaju rađanje od manje obrazovanih žena i žena crne populacije (u izvorniku: blacks) bez obzira na obrazovanje, dok tijekom druge polovine 20. stoljeća rastu stope izvanbračnih rođenja i za bijele i za crne žene, no stope za žene crne populacije daleko su više (Yang i Morgan, 2010). U Njemačkoj od većih etničkih skupina najveći fertilitet imaju Turci. Na drugome su mjestu stanovnici porijeklom iz bivše Jugoslavije, a na trećemu etnički Nijemci (Penn i Lambert, 2002). Slična je situacija i u Francuskoj, gdje stanovnici porijeklom iz zemalja Magreba imaju više stope fertiliteta od etničkih Francuza, iako se te razlike smanjuju (Penn i Lambert, 2002).

Razlike u fertilitetu između etničkih skupina prisutne su i u zemljama jugoistočne Europe. U Hrvatskoj najviše prosječne godišnje stope nataliteta od 1998. do 2008. imaju Romi. Slijede Albanci, Hrvati pa sve ostale narodnosti (Pavić, 2013). U Srbiji (bez Kosova), prema podacima iz 2002., Romi imaju dvostruko veću stopu nataliteta od etničkih Srba (Raduški, 2003). U Bugarskoj Romi imaju najviše ukupne stope fertiliteta, a slijede ih Turci pa etnički Bugari (Koytcheva i Philipov, 2008). Kroz cijelu drugu polovinu 20. stoljeća stope nataliteta Albanaca u Makedoniji bile su više nego kod Makedonaca i iako se stope nataliteta smanjuju kroz promatrano razdoblje, stope nataliteta Albanaca smanjuju se sporije (Brunnbauer, 2004).

Razlozi različitih stopa fertiliteta kod narodnosnih skupina u određenoj državi višestruki su i često međusobno isprepleteni, no tri su temeljne hipoteze koje pokušavaju objasniti te razlike: hipoteza socijalnih karakte- 
ristika, hipoteza statusa manjinske skupine i kulturna hipoteza (Forste i Tienda, 1996). Prema hipotezi socijalnih karakteristika, fertilitet određene skupine odraz je socijalnih karakteristika majki i/ili očeva, no prije svega majčina obrazovanja i obiteljskog prihoda. Stoga se razlike u fertilitetu između manjinske skupine i dominantnog naroda objašnjavaju različitim socioekonomskim statusom tih skupina. Hipoteza statusa manjinske skupine pretpostavlja u pravilu niži fertilitet manjinske skupine zbog (1) želje za akulturacijom članova manjinske skupine u dominantnu kulturu i (2) želje za socijalnom i ekonomskom mobilnošću njezinih članova. Iako te dvije hipoteze objašnjavaju veliki dio razlika u fertilitetu manjinskih skupina i dominantnog naroda, određeni dio varijabilnosti u fertilitetu najbolje se objašnjava kulturnim (svjetonazorskim, religijskim i dr.) značajkama pojedinog naroda, u što se ubrajaju i predodžbe o ulogama muškaraca i žena, idealnoj veličini obitelji, ponašanju članova obitelji i dr. Kulturna hipoteza svakako nadopunjuje prve dvije, no Forste i Tienda (1996) ističu važnost složenijeg međudjelovanja bioloških čimbenika (npr. dob pri menarhi), okruženja zajednice (segregacija, siromaštvo), utjecaja medija, obiteljske strukture, angažiranosti starijih članova obitelji (bake) i percepcije životnih ciljeva. Tim teorijskim okvirom objašnjavaju dotad neobjašnjene razlike $u$ fertilitetu, prije svega fertilitet meksičkih i drugih hispanoameričkih, a potom i skupina afričkog podrijetla u SAD-u (Forste i Tienda, 1996).

Istraživanja čiji rezultati mogu potkrijepiti jednu od navedenih hipoteza o razlikama $u$ fertilitetu etničkih skupina u Republici Hrvatskoj najčešće uspoređuju status pojedine etničke skupine s dominantnim hrvatskim narodom. Tako je npr. udio pripadnika srpske nacionalne manjine koji žive u kućanstvima s niskim prihodom oko dva i pol puta veći od udjela Hrvata u istim uvjetima, dok je za ostale nacionalne manjine taj udio veći za pedesetak posto (Šućur, 2009). Srbi povratnici nakon Domovinskog rata imaju uglavnom nepovoljnu starosnu strukturu, često neadekvatne stambene uvjete $\mathrm{i}$ nepovoljne obrazovne kvalifikacije, a samim tim i nepovoljan ekonomski status (Mesić i Bagić, 2011). Romi žive u prostorno i etnički segregiranim dijelovima naselja (u Međimurju, Šlezak, 2009) te imaju visoke stope fertiliteta (iako u smanjenju) i relativno visoki mortalitet dojenčadi (Šlezak, 2010). Osim prostorne marginaliziranosti Romi su marginalizirani i ekonomski i politički. Religijska pripadnost može biti indikator različitih obrazaca fertiliteta, a u Hrvatskoj se to odnosi na pripadnike muslimanske vjeroispovijesti, prije svega Bošnjake i dio Albanaca. Kod bošnjačke etničke skupine to je povezano i s pitanjem nacionalnog identiteta, koji je doživio preobrazbu u prvoj polovini devedesetih godina 20. stoljeća. Manjinske skupine često 
govore vrlo različitim jezikom (Talijani, Mađari, Albanci, Romi) i često žive na geografski ograničenim područjima, što može definirati njihov obrazovni, ekonomski i društveni status. Tako Talijani žive uglavnom u Istarskoj i Primorsko-goranskoj županiji, Mađari u Osječko-baranjskoj, Česi u Bjelovarsko-bilogorskoj, a Romi u Međimurskoj županiji i Gradu Zagrebu.

Geneza i dinamika razvoja većine etničkih skupina u Republici Hrvatskoj rezultat su višestoljetnih procesa (usp. Pavić, 2013). Ovdje će biti navedene samo osnovne odrednice kretanja stanovništva nacionalnih manjina. Na sadašnji broj srpskog stanovništva u Republici Hrvatskoj (186.633, 4,4\% ukupnog stanovništva) najviše su utjecali Drugi svjetski rat i Domovinski rat. Ukupni demografski gubici Srba u Drugome svjetskom ratu iznosili su 201.000 (Akrap, 2008), dok su u Domovinskom ratu poginula i nestala 6222 pripadnika srpske narodnosti. Broj izbjeglica iz RH u BiH i SiCG 1997. bio je 376.999, da bi se 2003. smanjio na 237.160 (Živić i Pokos, 2004). Udio Bošnjaka u RH rezultat je uglavnom migracija koje su počele austrougarskom okupacijom Bosne i Hercegovine, a intenzivirale se u razdoblju socijalističke Jugoslavije dolaskom ekonomskih migranata u potrazi za poslom (Čičak-Chand, 1999). Broj Talijana u Hrvatskoj uglavnom je rezultat njihova egzodusa nakon Drugoga svjetskog rata, tako da se njihov broj smanjio s oko 85.000 iz 1948. na malo više od 17.000 u 2011. (Klemenčič, 2006). Romi se u Hrvatskoj spominju već u 14. stoljeću u Dubrovniku, a na njihov su broj najviše utjecali imigracija iz Rumunjske u drugoj polovini 19. stoljeća te izrazito visoki fertilitet (Hrvatić, 2004), što je rezultiralo današnjim brojem od 16.975 Roma. Broj Čeha u Hrvatskoj rezultat je najvjerojatnije doseljavanja krajem 19. stoljeća (Pepeonik, 1967), dok je broj pripadnika mađarske nacionalne manjine rezultat višestoljetne povijesti zajedničke države. Broj Nijemaca u Republici Hrvatskoj spao je s 80.000 u 1910. na manje od 8000 u 1948. godini, uglavnom zbog raspada Austro-Ugarske Monarhije i progonâ nakon Drugoga svjetskog rata (Živić, 2008).

Dva su temeljna cilja ovog istraživanja. Prvi je cilj analizirati kretanje stopa fertiliteta za odabrane etničke skupine za razdoblje od 1998. do 2012. da bi se utvrdili različiti obrasci promjene dinamike fertiliteta, a time i mogući čimbenici koji različito djeluju kod pojedinih etničkih skupina. Drugi je cilj analizirati moguće razlike u stopama fertiliteta (opća stopa fertiliteta, stopa ukupnog fertiliteta, dobno specifične stope fertiliteta) između etničkih skupina u Republici Hrvatskoj. Analizirat će se navedene stope za 2011. godinu te će se opće stope fertiliteta manjinskih skupina standardizirati dobnom strukturom hrvatske ženske fertilne skupine. Na taj način dobit će se opća stopa fertiliteta koju bi etnička skupina imala kada bi zadržala dobno speci- 
fične stope fertiliteta, a imala dobnu strukturu hrvatske populacije. Razlika između hrvatske i pojedine manjinske opće stope fertiliteta razložit će se na doprinos dobno specifičnih stopa i doprinos dobne strukture. Na taj način utvrdit će se koji mogući socijalni, ekonomski i kulturni čimbenici utječu na različite obrasce fertiliteta manjinskih skupina.

\section{MATERIJAL I METODE}

Za izračun broja rođenih i stopa fertiliteta prema etničkoj pripadnosti upotrijebljeni su podaci o rođenjima za svaku godinu od 1998. do 2012. prema podacima iz obrazaca DEM-1. Tim obrascem evidentira se svako rođenje u Republici Hrvatskoj, a sadržava podatke o rođenju i statusu djeteta, kao i sociodemografske karakteristike majke i oca djeteta. Budući da se pri izračunu stopa fertiliteta upotrebljava broj žena fertilne dobi, etnička skupina svakog rođenja definirana je etničkom skupinom majke djeteta. Izabrane su sljedeće etničke skupine: hrvatska, albanska, bošnjačka, češka, mađarska, romska, slovenska, srpska, talijanska te ostali. Podatke o svakom rođenju Državni zavod za statistiku dostavio je bez identifikatora koji bi mogli otkriti identitet majke i oca.

Stope fertiliteta upotrijebljene $\mathrm{u}$ ovom istraživanju jesu opća stopa fertiliteta (GFR), stopa ukupnog fertiliteta (TFR) i dobno specifične stope fertiliteta (ASFR). Ukupni broj žena prema narodnosti i dobnim skupinama dostupan je iz popisa stanovništva 2001. i 2011. ${ }^{1}$ Za procjenu broja žena određene etničke skupine za godine između navedenog intervala interpoliran je linearni model broja žena s ishodišnim točkama u godinama popisa, a za procjenu broja izvan navedenog intervala ekstrapoliran je istovjetni model. Taj način svakako predstavlja pojednostavljenje kretanja broja žena fertilne dobi pojedinih etničkih skupina u godinama za koje taj broj nije poznat, no ujedno je i kompromis između nedostupnosti podataka i nepoznavanja dinamike promjene broja žena s jedne strane te jednostavnosti i izravnosti izračuna stopa fertiliteta s druge. $\mathrm{O}$ tom nedostatku vodilo se računa pri interpretaciji rezultata.

\footnotetext{
Ovo istraživanje ograničeno je na razdoblje popisa stanovništva 2001. i 2011. Potpunija analiza dinamike fertiliteta etničkih skupina u Hrvatskoj zahtijevala bi izračun stopa fertiliteta i prema podacima iz popisa 1953., 1971. i 1991. Na taj način dobio bi se uvid u dugoročni trend fertiliteta etničkih skupina u Hrvatskoj. Ti popisi rađeni su prema popisnoj metodologiji različitoj i od popisa 2001. i od popisa 2011. i stoga rezultati ne bi bili usporedivi. Prave razlike $\mathrm{u}$ fertilitetu etničkih skupina dobile bi se izračunom kohortne stope ukupnog fertiliteta (cohort TFR, completed TFR), kojom se utvrđuje stvarni fertilitet žena koje su izašle iz fertilnog razdoblja. Ta se mjera temelji na podacima o broju žena određene narodnosti i dobi koji su dostupni iz različitih popisa te stoga problem različitih metoda popisa utječe i na nju.
} 
Standardizirane stope fertiliteta izračunate su za 2011. jer za tu godinu postoje pouzdani podaci o etničkoj i dobnoj distribuciji žena u Republici Hrvatskoj, i to oni iz Popisa stanovništva. Time se izbjegava upotreba podataka iz godina gdje je taj broj procijenjen linearnim modelom. Ta je godina ujedno dovoljno recentna da bi bila zanimljiva za analizu. Dobno standardizirane stope fertiliteta izračunate su tako da su dobno specifične stope fertiliteta (stope fertiliteta za dobne kohorte žena 15 - 19, 20 - 24, 25 - 29, 30 - 34, 35 - 39, 40 - 44 i 45 - 49) žena manjinskih skupina pomnožene s udjelima istih kohorti u ukupnoj ženskoj fertilnoj populaciji hrvatske etničke skupine. Na taj način dobile su se stope fertiliteta koje bi manjinske skupine imale kada bi dijelile dobnu strukturu hrvatskih žena. Formalno:

$$
A S G F R^{M}=\sum_{i} F_{i}^{M} * C_{i}^{s}
$$

gdje je $A S G F R^{M}$ dobno standardizirana opća stopa fertiliteta manjinske skupine, $F_{i}^{M}$ jest dobno specifična stopa fertiliteta manjinske skupine, a $C_{i}^{s}$ udio odgovarajuće dobne skupine u ukupnom broju žena standardne populacije, u ovom slučaju hrvatske (Preston, Heuveline i Guillot, 2003).

Razlaganje (engl. decomposition) razlike općih stopa fertiliteta između hrvatske i manjinskih etničkih skupina provelo se prema formuli:

$$
\Delta=\sum_{i}\left(C_{i}^{M}+C_{i}^{N}\right) *\left[\frac{F_{i}^{M}+F_{i}^{N}}{2}\right]+\sum_{i}\left(F_{i}^{M}+F_{i}^{N}\right) *\left[\frac{C_{i}^{M}+C_{i}^{N}}{2}\right]
$$

gdje je $\Delta=G F R^{M}-G F R^{N}, G F R^{M}=\sum_{i} C_{i}^{M} * F_{i}^{M}, G F R^{N}=\sum_{i} C_{i}^{N} * F_{i}^{N}$.

$G F R^{M}$ jest opća stopa fertiliteta hrvatske etničke skupine, dok je $G F R^{N}$ opća stopa fertiliteta manjinske skupine (prema Preston, Heuveline i Guillot, 2003). Prvi pribrojnik jednadžbe (2) jest doprinos različitoga dobnog sastava razlici između općih stopa fertiliteta, dok je drugi pribrojnik doprinos različitih dobno specifičnih stopa fertiliteta razlici između općih stopa fertiliteta. Ako se svaki od tih pribrojnika podijeli s ukupnom razlikom između općih stopa fertiliteta $(\Delta)$, dobije se udio razlike koji se pripisuje razlikama u dobnom sastavu i udio razlike koji se pripisuje razlikama u dobno specifičnim stopama fertiliteta. Moguće je da razlika između općih stopa fertiliteta ima i treću, rezidualnu komponentu ili komponentu interakcije, pa se u tom slučaju razlaganje izvodi prema formuli:

$$
\Delta=\sum_{i} C_{i}^{M} *\left(F_{i}^{M}-F_{i}^{N}\right)+\sum_{i} F_{i}^{M} *\left(C_{i}^{M}-C_{i}^{N}\right)-\sum_{i}\left(F_{i}^{M}-F_{i}^{N}\right) *\left(C_{i}^{M}-C_{i}^{N}\right)
$$


gdje se prva dva elementa jednadžbe interpretiraju kao doprinos razlika u dobno specifičnim stopama fertiliteta i doprinos razlika u dobnom sastavu, dok je treći element interakcijski; on je pozitivan ako je $F_{i}^{N}$ visok u odnosu na $F_{i}^{M}$ za dob gdje je $C_{i}^{N}$ visok u odnosu na $C_{i}^{M}$ (prema Preston, Heuveline i Guillot, 2003).

Kao početna godina istraživanja izabrana je 1998. (usp. Pavić, 2013) zbog dostupnosti podataka za cijeli teritorij $\mathrm{RH}$ nakon mirne reintegracije Podunavlja kao i zbog neusporedivosti podataka vitalne statistike iz ranijeg razdoblja zbog uvođenja bilježenja demografskih događaja prema načelu ukupno prisutnog broja stanovnika 1998.

\section{REZULTATI}

U tablici 1 naveden je broj žena fertilne dobi za odabrane etničke skupine u 2001. i 2011. koji je poslužio za procjenu broja žena linearnim modelom u ostalim ispitivanim godinama. Vidljivo je smanjenje broja fertilnih žena kod hrvatske, češke, mađarske, slovenske, srpske i talijanske etničke skupine te kod ostalih, dok kod albanske, bošnjačke i romske etničke skupine taj broj raste.

Tablica 1. Broj žena fertilne dobi (15 - 49 godina) u Republici Hrvatskoj prema narodnosti

Table 1. The number of women in fertile age (15 - 49 years) in the Republic of Croatia by ethnicity

\begin{tabular}{|c|c|c|c|c|c|c|c|c|c|c|}
\hline \multirow[b]{2}{*}{ Godina } & \multicolumn{10}{|c|}{ Narodnost } \\
\hline & 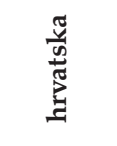 & 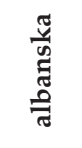 & 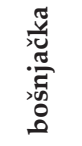 & 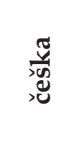 & 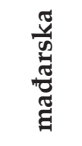 & 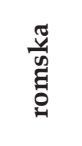 & $\begin{array}{l}\frac{\tilde{v}}{\omega} \\
\frac{\tilde{D}}{\tilde{D}} \\
\frac{0}{n}\end{array}$ & $\frac{\tilde{\tilde{w}}}{\tilde{\omega}}$ & 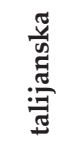 & 苛 \\
\hline 2001. & 980.986 & 3610 & 5723 & 2193 & 3278 & 2148 & 2708 & 38.064 & 3821 & 37.590 \\
\hline 2011. & 898.810 & 4531 & 7458 & 1852 & 2522 & 3965 & 1634 & 27.288 & 3239 & 21.649 \\
\hline
\end{tabular}

Izvori: Popis stanovništva, kućanstava i stanova 2001., Državni zavod za statistiku, Zagreb, 2001.; Popis stanovništva, kućanstava i stanova 2011., Državni zavod za statistiku, Zagreb, 2011.

Broj rođene djece prema etničkoj pripadnosti pokazuje zanimljive obrasce (tablica 2, slika 1). ${ }^{2}$ Pad broja rođene djece bilježe hrvatska i slovenska

2 U grafičkim prikazima na slikama 1, 2 i 3 ravna linija prikazuje linearni trend, a zatamnjeno područje intervale pouzdanosti linearnog modela (95\%). 
narodnost, s tim da kod obje, a posebno kod hrvatske, jednostavni linearni trend ne objašnjava dobro navedenu promjenu, tj. intervali pouzdanosti vrlo su široki. Čini se da je kod hrvatske narodnosti došlo do naglog smanjenja broja rođenih krajem 20. i početkom 21. stoljeća, da bi se taj broj blago povećao i ustalio u drugoj polovini prvoga desetljeća 21. stoljeća. Albanska, češka i mađarska etnička skupina bilježe blagi porast broja rođenih, premda je i on upitan zbog velike međugodišnje varijacije u broju rođenih, posebice kod češke narodnosti. Bošnjačka i romska narodnost bilježe izraženi rast broja rođenih, dok je kod srpske, talijanske i ostalih narodnosti rast broja rođenih nešto blaži.

Tablica 2. Broj rođene djece prema narodnosti majke od 1998. do 2012.

Table 2. The number of births by mother's ethnicity, 1998 - 2012

\begin{tabular}{|c|c|c|c|c|c|c|c|c|c|c|}
\hline \multirow[b]{2}{*}{ Godina } & \multicolumn{10}{|c|}{ Narodnost } \\
\hline & 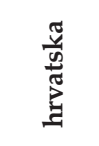 & 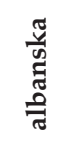 & 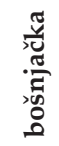 & 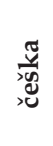 & 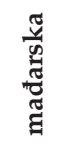 & $\begin{array}{l}\tilde{\tilde{v}} \\
\tilde{\omega} \\
\tilde{0}\end{array}$ & $\begin{array}{l}\frac{\pi}{\tilde{\omega}} \\
\tilde{D} \\
\overrightarrow{0} \\
\frac{0}{\omega}\end{array}$ & 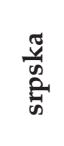 & 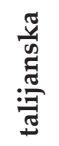 & 节 \\
\hline 1998. & 44.041 & 223 & 13 & 68 & 83 & 307 & 53 & 850 & 64 & 1291 \\
\hline 1999. & 41.884 & 255 & 27 & 81 & 77 & 366 & 40 & 807 & 45 & 1461 \\
\hline 2000 & 40.443 & 236 & 21 & 56 & 89 & 357 & 46 & 833 & 82 & 1499 \\
\hline 2001. & 37.443 & 262 & 47 & 63 & 97 & 427 & 28 & 798 & 66 & 1668 \\
\hline 2002. & 36.828 & 220 & 42 & 65 & 85 & 370 & 24 & 812 & 70 & 1543 \\
\hline 2003. & 36.558 & 240 & 73 & 77 & 90 & 403 & 31 & 828 & 70 & 1229 \\
\hline 2004. & 37.000 & 247 & 124 & 74 & 95 & 396 & 31 & 889 & 75 & 1347 \\
\hline 2005. & 38.607 & 247 & 134 & 74 & 92 & 436 & 39 & 954 & 61 & 1808 \\
\hline 2006. & 37.375 & 195 & 134 & 75 & 100 & 438 & 22 & 878 & 78 & 2123 \\
\hline 2007. & 38.178 & 246 & 154 & 74 & 100 & 464 & 29 & 890 & 72 & 1678 \\
\hline 2008 & 39.723 & 252 & 189 & 83 & 112 & 433 & 25 & 927 & 90 & 1858 \\
\hline 2009. & 40.550 & 249 & 197 & 70 & 107 & 517 & 27 & 992 & 95 & 1911 \\
\hline 2010. & 39.707 & 253 & 198 & 79 & 82 & 524 & 31 & 884 & 82 & 1691 \\
\hline 2011. & 37.556 & 253 & 219 & 55 & 85 & 538 & 37 & 902 & 86 & 1603 \\
\hline 2012. & 38.016 & 282 & 233 & 72 & 89 & 544 & 32 & 866 & 95 & 1663 \\
\hline
\end{tabular}

Izvori: Obrasci DEM-1, DZS, Zagreb 
Slika 1. Broj rođenih u RH od 1998. do 2012. prema narodnosti majke

Figure 1. The number of births in the Republic of Croatia by mother's ethnicity, $1998-2012$
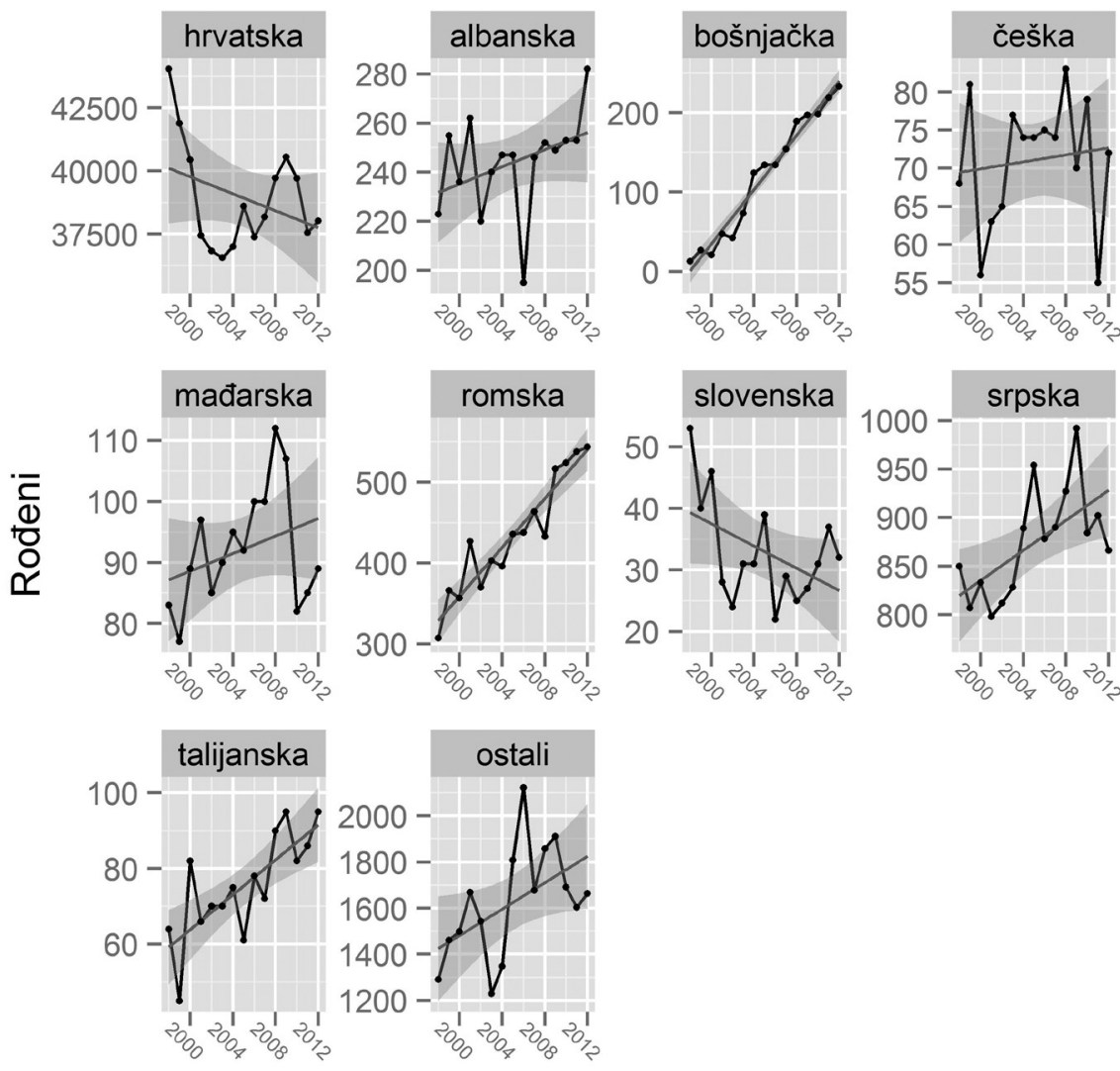

\section{Godina}

Opća stopa fertiliteta (tablica 3, slika 2) izrazito raste kod bošnjačke, srpske, talijanske i ostalih narodnosti, nešto blaže kod češke i slovenske (uz ogradu o širokim intervalima pouzdanosti), dok kod hrvatske prati dinamiku promjene broja rođenih $\mathrm{u}$ istom razdoblju. $\mathrm{U}$ promatranom razdoblju opća stopa fertiliteta pada za albansku i romsku narodnost. Gotovo je identična situacija i kod stope ukupnog fertiliteta, s tim da je kod češke narodnosti rast još blaži, a intervali pouzdanosti još su širi (tablica 4, slika 3). 
Tablica 3. Procijenjene opće stope fertiliteta (GFR) prema narodnosti majke za razdoblje od 1998. do 2012.

Table 3. Estimated general fertility rates (GFR) by mother's ethnicity, $1998-2012$

\begin{tabular}{|c|c|c|c|c|c|c|c|c|c|c|}
\hline \multirow[b]{2}{*}{ Godina } & \multicolumn{10}{|c|}{ Narodnost } \\
\hline & 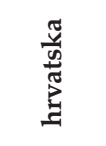 & 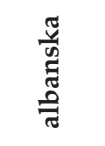 & 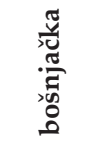 & 丞 & 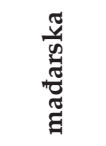 & 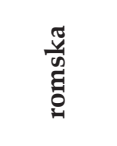 & $\begin{array}{l}\frac{\tilde{v}}{\tilde{v}} \\
\overrightarrow{\tilde{D}} \\
\frac{0}{\omega}\end{array}$ & $\begin{array}{l}\frac{\tilde{w}}{\omega} \\
\frac{\vec{w}}{\omega}\end{array}$ & 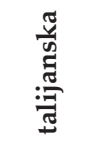 & गี \\
\hline 1998. & 43,821 & 66,893 & 2,499 & 29,626 & 2,682 & 193,399 & 17,491 & 20,607 & 16,018 & 31,695 \\
\hline 1999. & 42,030 & 75,019 & 5,022 & 35,822 & 22,454 & 206,209 & 13,686 & 20,065 & 11,429 & 36,637 \\
\hline 2000. & 40,920 & 67,370 & 3,784 & 25,594 & 26,539 & 183,594 & 16,694 & 21,486 & 21,138 & 39,404 \\
\hline 2001. & 38,185 & 72,576 & 8,212 & 28,728 & 29,591 & 200,652 & 10,340 & 21,017 & 17,273 & 45,943 \\
\hline 2002. & 37,887 & 59,696 & 7,123 & 30,108 & 26,543 & 159,248 & 9,229 & 21,981 & 18,603 & 43,505 \\
\hline 2003. & 37,910 & 63,518 & 12,026 & 36,239 & 28,783 & 160,468 & 12,434 & 23,058 & 18,895 & 36,481 \\
\hline 2004. & 38,697 & 63,814 & 19,861 & 35,395 & 31,135 & 148,528 & 12,994 & 25,523 & 20,568 & 41,819 \\
\hline 2005. & 40,727 & 62,085 & 20,882 & 35,982 & 30,918 & 152,706 & 17,117 & 28,264 & 17,000 & 58,885 \\
\hline 2006. & 39,771 & 47,906 & 20,332 & 37,083 & 34,483 & 143,301 & 10,134 & 26,870 & 22,096 & 72,216 \\
\hline 2007. & 40,981 & 59,098 & 22,768 & 37,216 & 35,406 & 144,216 & 14,053 & 28,166 & 20,739 & 61,087 \\
\hline 2008. & 43,017 & 59,229 & 27,243 & 42,470 & 40,745 & 126,904 & 12,780 & 30,373 & 26,365 & 71,657 \\
\hline 2009. & 44,308 & 57,284 & 27,704 & 36,455 & 40,027 & 143,825 & 14,604 & 33,692 & 28,313 & 78,350 \\
\hline 2010. & 43,779 & 56,996 & 27,181 & 41,885 & 31,568 & 139,032 & 17,802 & 31,165 & 24,870 & 73,226 \\
\hline 2011. & 41,785 & 55,838 & 29,364 & 29,698 & 33,703 & 135,687 & 22,644 & 33,055 & 26,551 & 74,368 \\
\hline 2012. & 42,688 & 60,998 & 30,531 & 39,606 & 36,380 & 131,430 & 20,962 & 33,040 & 29,867 & 83,222 \\
\hline
\end{tabular}


Slika 2. Procijenjene opće stope fertiliteta (GFR) u RH prema narodnosti majke od 1998. do 2012.

Figure 2. Estimated general fertility rates (GFR) in the Republic of Croatia by mother's ethnicity, $1998-2012$
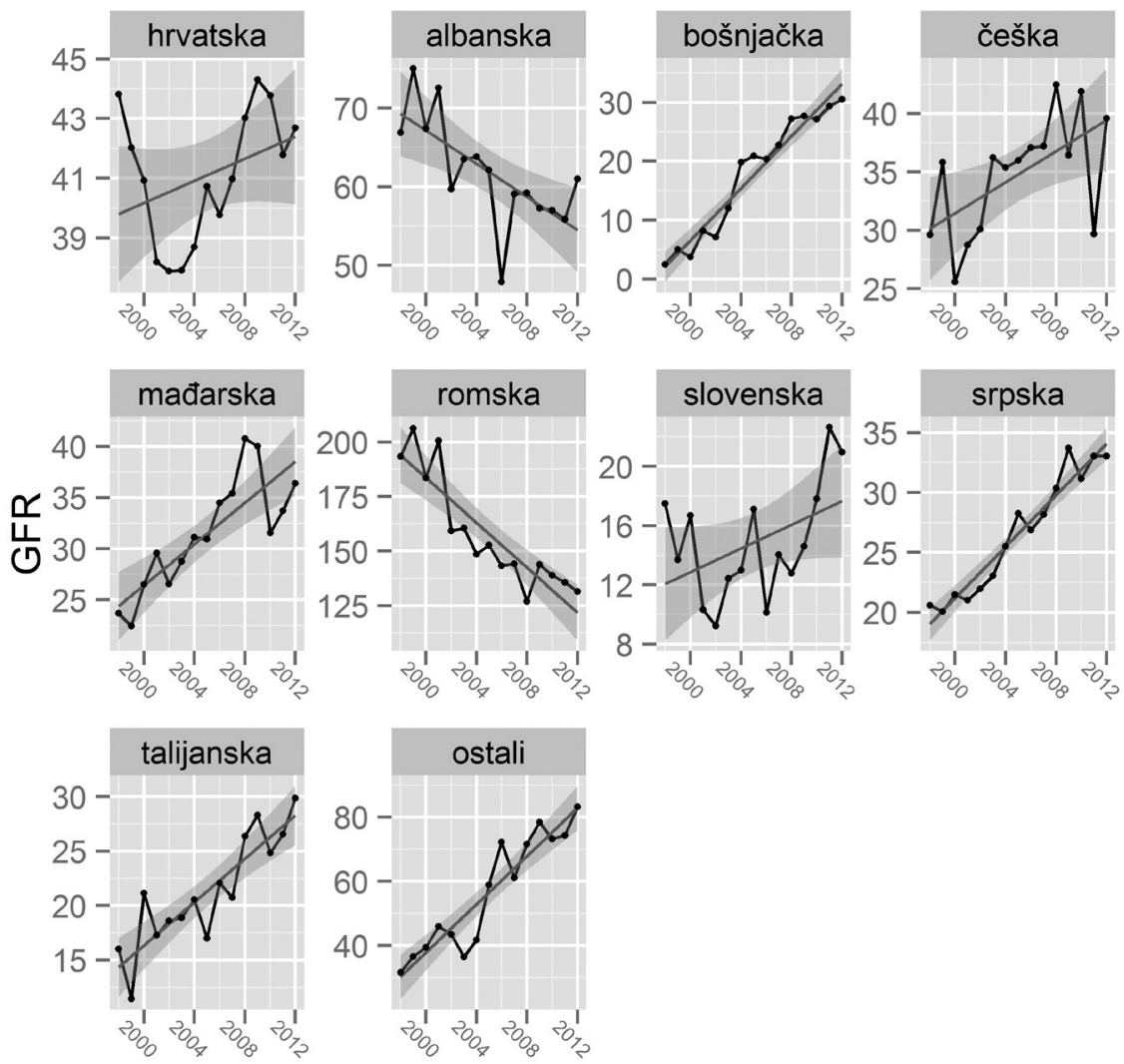

\section{Godina}


Tablica 4. Procijenjene stope ukupnog fertiliteta (TFR) prema narodnosti majke za razdoblje od 1998. do 2012.

Table 4. Estimated total fertility rates (TFR) by mother's ethnicity, 1998 2012

\section{Narodnost}

\begin{tabular}{|c|c|c|c|c|c|c|c|c|c|c|}
\hline Godina & 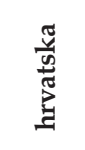 & $\begin{array}{l}\frac{\tilde{v}}{\tilde{w}} \\
\text { ప్ } \\
\text { ప్ల }\end{array}$ & 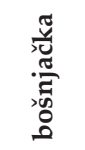 & 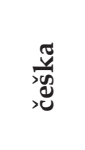 & 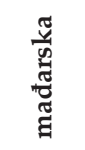 & 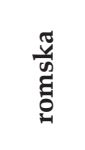 & $\begin{array}{l}\frac{\pi}{\tilde{\sigma}} \\
\frac{0}{0} \\
\frac{0}{\omega}\end{array}$ & $\begin{array}{l}\frac{\pi}{\tilde{w}} \\
\stackrel{2}{\omega}\end{array}$ & 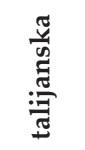 & 䒕 \\
\hline 1998. & 1,580 & 2,099 & 0,098 & 1,237 & 1,004 & 5,408 & 0,932 & 0,937 & 0,624 & 1,228 \\
\hline 1999. & 1,513 & 2,331 & 0,205 & 1,503 & 0,952 & 5,861 & 0,616 & 0,909 & 0,455 & 1,437 \\
\hline 2000. & 1,470 & 2,123 & 0,145 & 1,014 & 1,133 & 5,073 & 0,846 & 0,948 & 0,787 & 1,526 \\
\hline 2001. & 1,370 & 2,303 & 0,316 & 1,185 & 1,245 & 5,637 & 0,585 & 0,920 & 0,656 & 1,773 \\
\hline 2002. & 1,357 & 1,888 & 0,277 & 1,238 & 1,100 & 4,468 & 0,474 & 0,955 & 0,692 & 1,702 \\
\hline 2003. & 1,356 & 2,022 & 0,460 & 1,478 & 1,207 & 4,620 & 0,617 & 0,991 & 0,704 & 1,408 \\
\hline 2004. & 1,381 & 2,039 & 0,758 & 1,398 & 1,265 & 4,223 & 0,669 & 1,092 & 0,751 & 1,602 \\
\hline 2005. & 1,450 & 1,998 & 0,794 & 1,392 & 1,228 & 4,318 & 0,777 & 1,185 & 0,615 & 2,239 \\
\hline 2006. & 1,412 & 1,551 & 0,767 & 1,468 & 1,389 & 4,161 & 0,564 & 1,112 & 0,788 & 2,746 \\
\hline 2007. & 1,450 & 1,918 & 0,859 & 1,438 & 1,377 & 4,183 & 0,649 & 1,145 & 0,725 & 2,282 \\
\hline 2008. & 1,518 & 1,938 & 1,028 & 1,594 & 1,606 & 3,773 & 0,582 & 1,200 & 0,899 & 2,667 \\
\hline 2009. & 1,557 & 1,887 & 1,038 & 1,312 & 1,504 & 4,321 & 0,678 & 1,296 & 0,975 & 2,899 \\
\hline 2010. & 1,531 & 1,875 & 1,007 & 1,516 & 1,191 & 4,143 & 0,921 & 1,168 & 0,818 & 2,707 \\
\hline 2011. & 1,456 & 1,849 & 1,090 & 1,045 & 1,276 & 4,065 & 0,978 & 1,223 & 0,849 & 2,733 \\
\hline 2012. & 1,482 & 2,043 & 1,130 & 1,369 & 1,298 & 3,896 & 0,923 & 1,201 & 0,942 & 3,050 \\
\hline
\end{tabular}


Slika 3. Procijenjene stope ukupnog fertiliteta (TFR) u RH prema narodnosti majke od 1998. do 2012.

Figure 3. Estimated total fertility rates (TFR) in the Republic of Croatia by mother's ethnicity, 1998 - 2012
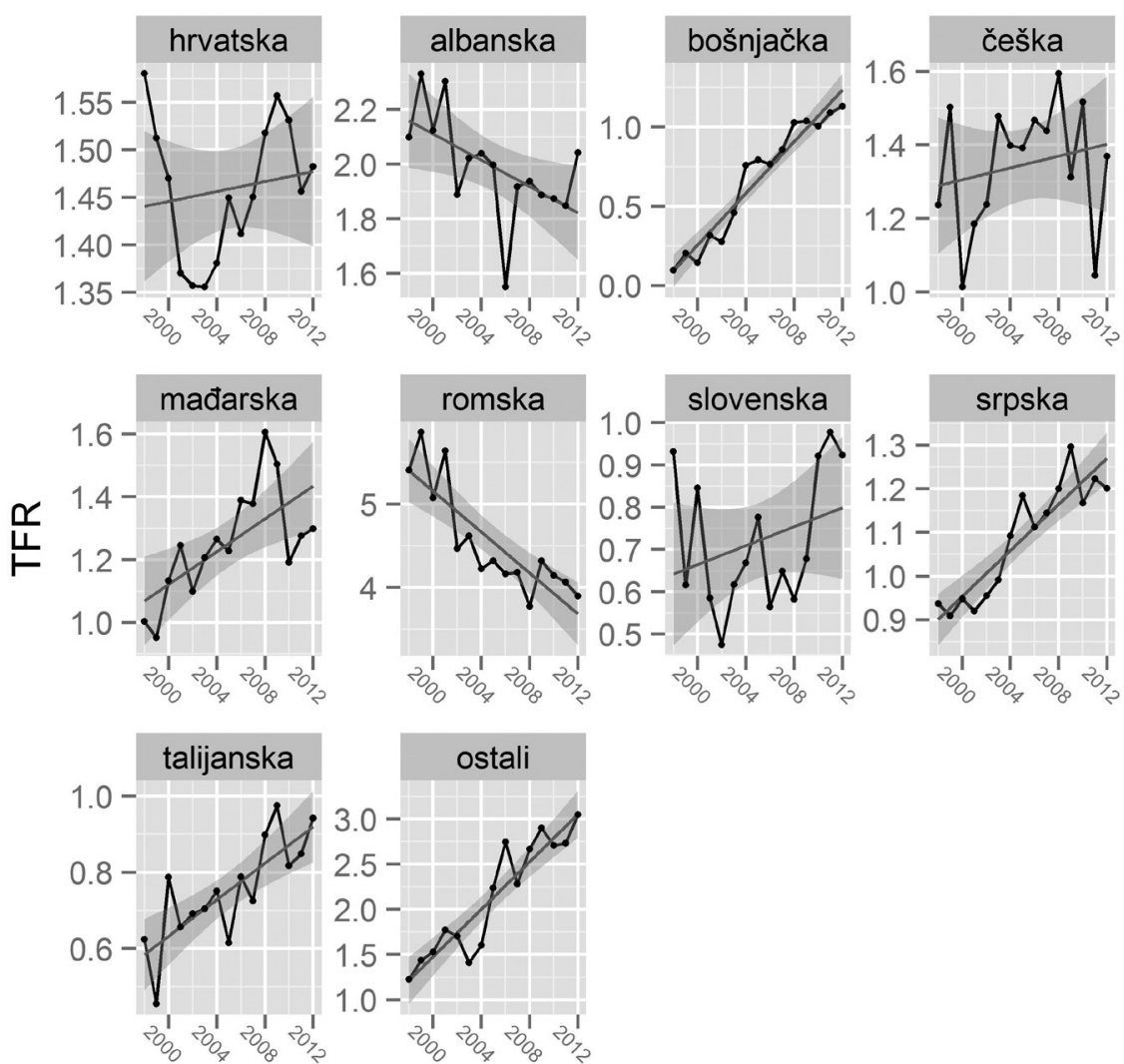

\section{Godina}

Standardizirane opće stope fertiliteta (dobno specifične stope fertiliteta pojedine narodnosti kombinirane s dobnim udjelima hrvatske narodnosti) navedene $\mathrm{u}$ tablici 5 ne pokazuju prevelike razlike od stvarnih. Kada bi imale dobni sastav hrvatske populacije, albanska, romska i talijanska populacija imale bi nižu opću stopu fertiliteta, a najvidljivija razlika bila bi u romskoj skupini. Ostale etničke skupine imale bi nešto višu opću stopu fertiliteta, iako taj »dobitak« nije velik. Razlike u općim stopama fertiliteta između hr- 
vatske etničke skupine i nacionalnih manjina navedene su u tablici 6. Opća stopa fertiliteta hrvatske narodnosti niža je od albanske, romske i skupine »ostali«, dok od svih preostalih ima višu stopu. Vidljivo je da su razlike u općim stopama fertiliteta između hrvatske i drugih narodnosti više uvjetovane razlikama u dobno specifičnim stopama fertiliteta (tablica 6, slika 4), a manje razlikama u dobnom sastavu ženskoga fertilnog stanovništva (tablica 6, slika 5). Tako različite dobno specifične stope fertiliteta objašnjavaju od oko 59\% razlike u općim stopama fertiliteta između hrvatske i slovenske etničke skupine do oko $97 \%$ te razlike između hrvatske i češke etničke skupine. I kod talijanske skupine i kod ostalih razlika u dobno specifičnim stopama fertiliteta najveća je odrednica razlike u općim stopama fertiliteta.

Tablica 5. Standardizirane opće stope fertiliteta i stvarne opće stope fertiliteta*

Table 5. Standardised general fertility rates and real general fertility rates

\begin{tabular}{lcc}
\hline \multirow{2}{*}{ Narodnost } & \multicolumn{2}{c}{ Stope fertiliteta } \\
\cline { 2 - 3 } & Stand. GFR & GFR \\
\hline albanska & 52,682 & 55,838 \\
\hline bošnjačka & 31,129 & 29,364 \\
\hline češka & 29,974 & 29,698 \\
\hline mađarska & 36,348 & 33,703 \\
\hline romska & 112,586 & 135,687 \\
\hline slovenska & 28,103 & 22,644 \\
\hline srpska & 34,751 & 33,055 \\
\hline talijanska & 24,705 & 26,551 \\
\hline ostali & 77,419 & 74,368 \\
\hline
\end{tabular}

* Dobno specifične stope fertiliteta pojedinih narodnosti pomnožene su s dobnim udjelima hrvatske narodnosti 2011. 
Tablica 6. Razlika općih stopa fertiliteta i razložena razlika na komponente dobno specifičnih stopa fertiliteta i dobne strukture nacionalnih manjina RH u usporedbi s Hrvatima 2011.

Table 6. Difference between general fertility rates and the difference decomposed to the components of age-specific fertility rates and the age structure of ethnic minorities in Croatia in comparison to Croats in 2011

\begin{tabular}{lccccccc}
\hline \multirow{2}{*}{ Narodnost } & GFR & Razlika & $\begin{array}{c}\text { Razlika } \\
- \text { stope }\end{array}$ & $\begin{array}{c}\text { Razlika } \\
\text {-dob }\end{array}$ & Interakcija & $\begin{array}{c}\text { Udio - } \\
\text { stope }\end{array}$ & $\begin{array}{c}\text { Udio - } \\
\text { dob }\end{array}$ \\
\cline { 2 - 7 } albanska & 55,838 & $-14,053$ & $-11,605$ & $-2,448$ & 0,826 & 0,174 \\
\hline bošnjačka & 29,364 & 12,420 & 10,356 & 2,064 & 0,834 & 0,166 \\
\hline češka & 29,698 & 12,087 & 11,732 & 0,354 & 0,971 & 0,029 \\
\hline mađarska & 33,703 & 8,081 & 5,952 & 2,128 & & 0,737 & 0,263 \\
\hline romska & 135,687 & $-93,903$ & $-81,673$ & $-12,230$ & & 0,870 & 0,130 \\
\hline slovenska & 22,644 & 19,140 & 11,392 & 7,749 & & 0,595 & 0,405 \\
\hline srpska & 33,055 & 8,729 & 7,266 & 1,464 & & 0,832 & 0,168 \\
\hline talijanska & 26,551 & 15,233 & 17,079 & $-1,496$ & 0,351 & & \\
\hline ostali & 74,368 & $-32,261$ & $-35,635$ & 0,828 & $-2,546$ & & \\
\hline
\end{tabular}


Slika 4. Dobno specifične stope fertiliteta (ASFR) fertilnih skupina žena prema narodnosti u RH 2011.

Figure 4. Age-specific fertility rates (ASFR) of fertile groups of women by ethnicity in the Republic of Croatia in 2011

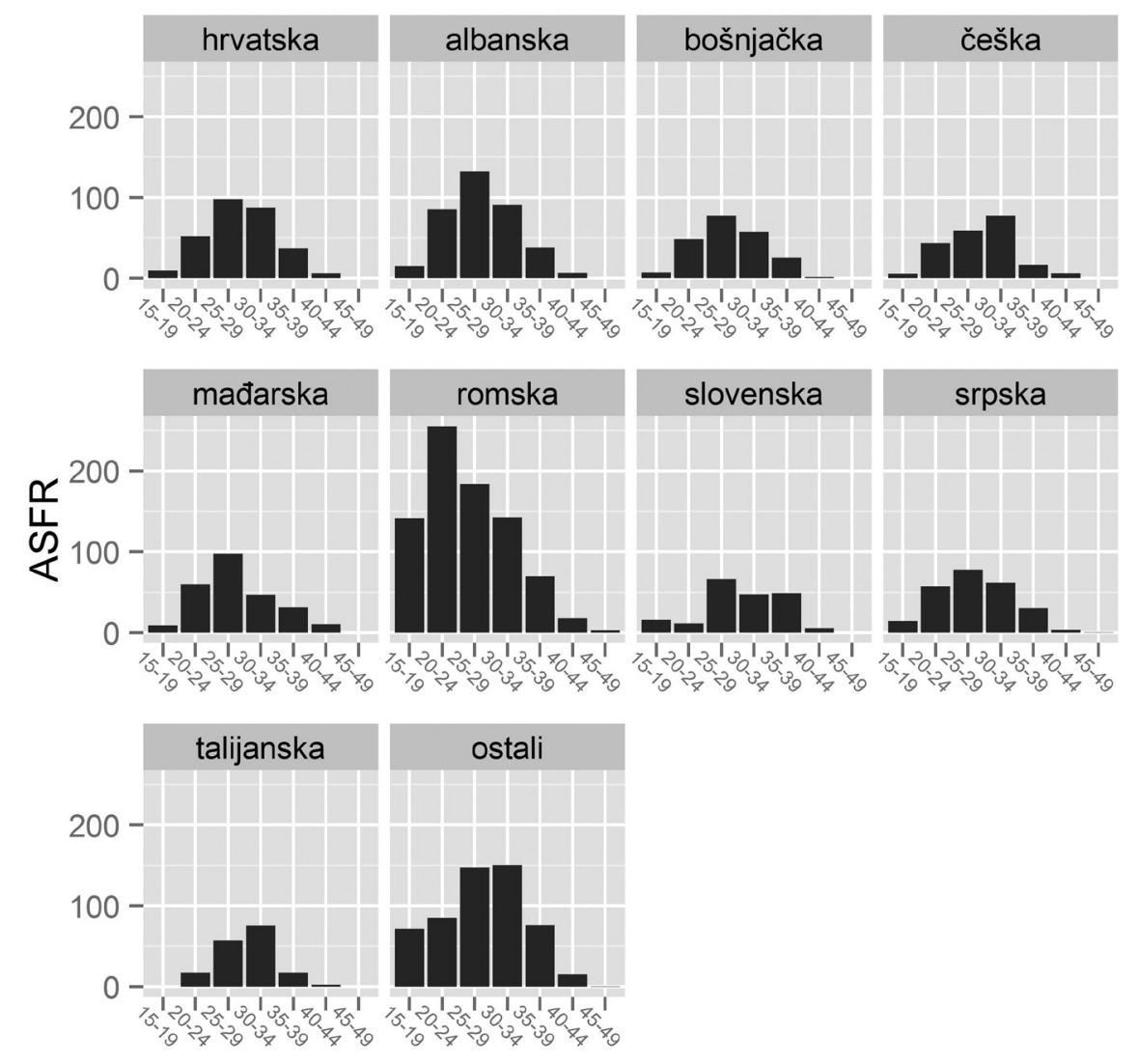

Dobne skupine 
Slika 5. Dobni udjeli fertilnih skupina žena prema narodnosti u RH 2011.

Figure 5. Age proportions of fertile groups of women by ethnicity in the Republic of Croatia in 2011
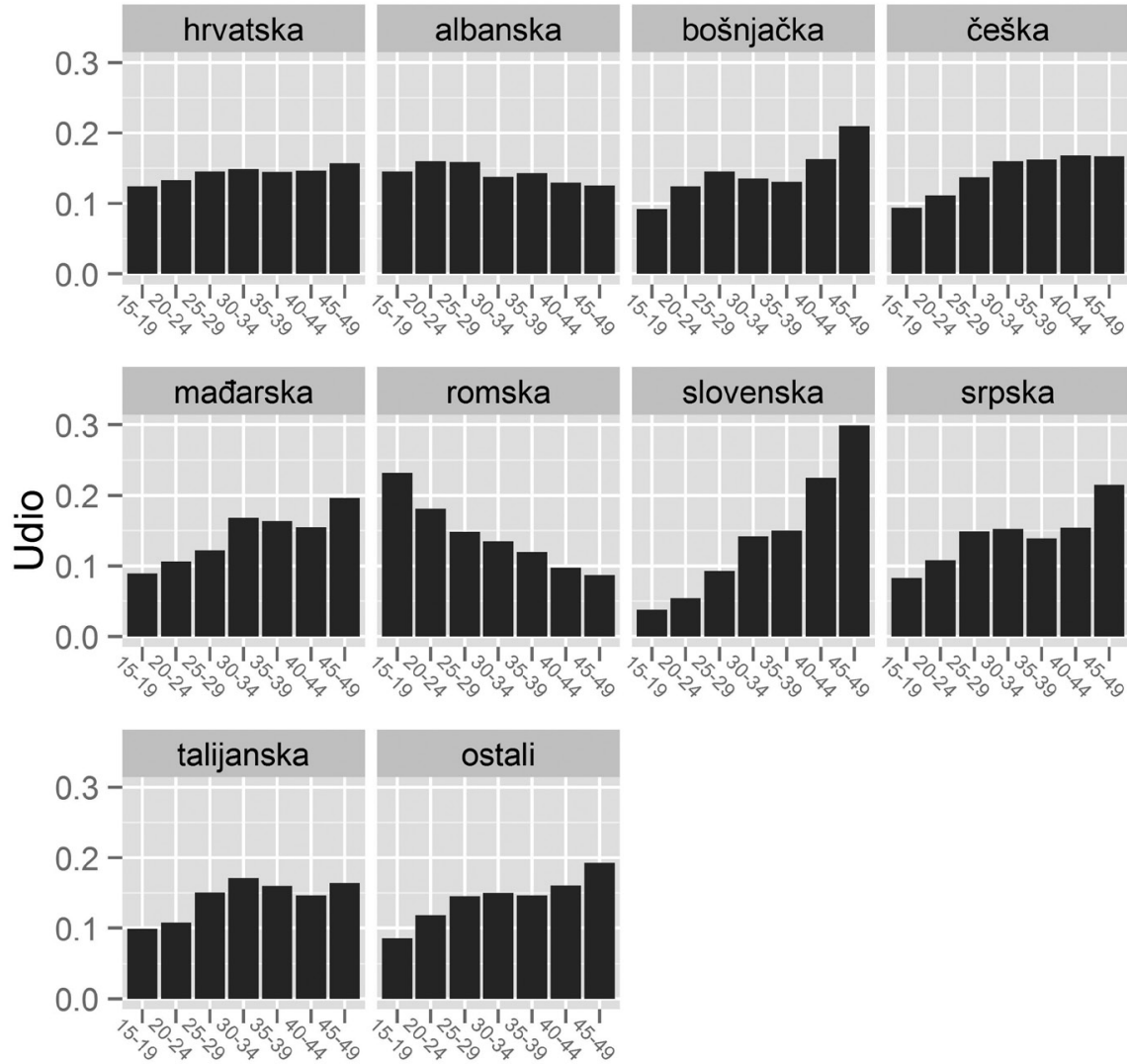

\section{Dobne skupine}

\section{RASPRAVA}

Trend promjene opće stope fertiliteta i stope ukupnog fertiliteta u promatranom razdoblju različit je za etničke skupine u Hrvatskoj, takav da ga se može podijeliti na tri skupine; prvu skupinu čine albanska i romska zajednica, kod kojih je vidljiv izraženi pad stopa fertiliteta. Kod bošnjačke, mađarske, srpske, talijanske i ostalih narodnosti vidljiv je izraženi rast, dok 
se za hrvatsku, češku i slovensku narodnost čini da stope rastu, međutim vrlo blago, s širokim intervalima pouzdanosti linearnog modela, te je upitno koliko jednostavni model rasta objašnjava dinamiku fertiliteta. Takva različitost kretanja fertiliteta predstavlja poteškoću za interpretaciju podataka jer pretpostavlja različite društvene, ekonomske i kulturne obrasce koji utječu na etničke skupine. Iako je postojanje različitih utjecaja na etničke skupine vjerojatno, ovdje će se tvrditi da je trend fertiliteta etničkih skupina u Hrvatskoj od 1998. do 2012. prije svega rezultat metodoloških razlika pri popisima stanovništva 2001. i 2011., kao i promjena u percepciji pripadnosti etničkoj skupini kod pojedinih narodnosti.

Kao što je već navedeno, broj fertilnih žena etničkih skupina za godine 1998. - 2000, 2002. - 2010. i 2012. izračunat je upotrebom broja fertilnih žena prema popisima 2001. i 2011. Broj fertilnih žena (ukupno ili prema dobnim skupinama) nazivnik je pri izračunu svih upotrijebljenih stopa fertiliteta, tako da sve ono što utječe na broj žena u 2001. i 2011. godini utječe i na sve izračunate stope fertiliteta. Za razliku od popisa stanovništva iz 1991., gdje su stanovnici popisivani prema prijavljenom prebivalištu, bez obzira na to gdje se nalazili u trenutku popisa, popisi 2001. i 2011. koristili su se metodologijom uobičajenog mjesta stanovanja, kojom se popisuju stanovnici koji u mjestu ili zemlji imaju uobičajeno boravište, bez obzira na to gdje su službeno prijavljeni. No i ta dva popisa međusobno se razlikuju u jednom detalju. U popisane građane 2001. ulazile su osobe koje su boravile $\mathrm{u}$ inozemstvu dulje od jedne godine, ali su se u Hrvatsku vraćale sezonski ili mjesečno, dok su 2011. takve osobe bile popisane ako je njihova učestalost povratka u RH bila jednom tjedno, a ne više sezonski ili mjesečno. Na taj način popisani su samo oni stanovnici RH koji žive izvan njezinih granica, a dolaze u RH relativno često. Iz popisa 2011. bile su isključene i osobe koje su boravile izvan RH kraće od jedne godine, ali koje su namjeravale boraviti u inozemstvu godinu ili dulje, što u popisu 2001. nije bio slučaj. ${ }^{3} \mathrm{Zbog}$ tih metodoloških razlika (iako ne nužno samo zbog njih) broj popisanih građana nekih etničkih skupina smanjio se između dva popisa.

Kako je ta činjenica utjecala na trend stopa fertiliteta? Kada bi broj rođenih kroz godine za pojedinu etničku skupinu bio otprilike isti, samo smanjenje broja fertilnih žena dovelo bi do povećanja stopa fertiliteta. No u nekim etničkim skupinama u RH fertilitet raste, dok u drugima pada, a u nekim se skupinama trend fertiliteta ne može jednostavno opisati linearnim modelom. Ono što se čini vrlo indikativnim jest činjenica da se broj fertilnih žena

Popis stanovništva, kućanstava i stanova 2011. godine: metodološka objašnjenja, http://www.dzs. hr/Hrv/census2011/results/censusmetod.htm. 
smanjuje samo u onim etničkim skupinama (uz iznimku bošnjačke i češke, o čemu više poslije) čija matična etnička država graniči s RH. Tako se između popisa smanjuje broj pripadnica mađarske, slovenske, srpske, talijanske i ostalih etničkih skupina, pa čak i broj pripadnica hrvatske narodnosti. S druge strane, ne smanjuje se broj pripadnica albanske i romske narodnosti. Ta činjenica upućuje na to da je 2001. bilo popisano više pripadnika etničkih zajednica u RH koji su živjeli u »matičnim « etničkim državama koje graniče s RH, ili su u tim državama imali veći etnički korpus, a koji su povremeno dolazili u RH. Godine 2011. veliki broj njih nije popisan jer se kriterij učestalosti dolazaka u RH postrožio (jednom tjedno). $S$ druge strane, albansku i romsku zajednicu ta promjena nije pogodila jer te zajednice nemaju matičnu državu koja graniči s RH i gdje bi njihovi pripadnici mogli uobičajeno boraviti. Čini se stoga da je promjena popisne metodologije utjecala na broj popisanih žena fertilne dobi, a samim tim i na stope fertiliteta etničkih skupina. Povećanje stopa fertiliteta tijekom međupopisnog razdoblja rezultat je ponajprije tog fenomena, iako je na rast romske i albanske populacije sigurno utjecao i njihov visoki fertilitet.

Da bi to objašnjenje bilo vjerodostojno, povećanje stopa fertiliteta trebalo bi biti rezultat uglavnom smanjenja broj fertilnih žena, dok broj rođenih ne bi smio previše varirati u promatranom razdoblju, pogotovo ne u suprotnom smjeru od broja žena u fertilnoj dobi, jer u tom slučaju nije jasno je li povećanje stope proizvod smanjenja broja žena ili povećanja broja rođenih. Za predloženo objašnjenje ključno je da broj rođenih predstavlja indikator fertiliteta stvarne populacije koja živi u RH, jer prijava rođenja obično se obavlja u onoj državi u kojoj osoba stvarno živi. Trudnoću obično prati ginekolog od njezina utvrđivanja pa sve do porođaja, tako da je malo vjerojatno da će osoba otići u drugu državu samo roditi. U ovom istraživanju pokazano je da broj rođenih kod etničkih skupina u RH varira, no analizom za svaku pojedinu narodnost pokazat će se da je smanjenje broja fertilnih žena izglednije objašnjene povećanja stopa fertiliteta.

Ono što posebno iznenađuje jest strelovit rast stopa fertiliteta srpske etničke skupine $u$ promatranom razdoblju. Broj rođenja kod Srba raste, što bi se moglo dovesti u vezu s povratkom srpskog stanovništva u RH nakon završetka ratnih sukoba, mirne reintegracije Podunavlja i općenito poboljšanja manjinskog statusa u RH. No, prema rezultatima popisa stanovništva, unatoč povratku Srba u RH, njihov broj pada, a pada i broj fertilnih žena. Kako navode Mesić i Bagić, u Hrvatskoj je 2010. bilo registrirano 130.200 srpskih povratnika, međutim udio onih koji su stalno boravili na području RH bio je oko trećine (Mesić i Bagić, 2011). Isto tako, srpska nacionalna ma- 
njina ima nepovoljnu dobnu strukturu, niski socioekonomski status, visoku stopu nezaposlenosti, probleme sa stambenim zbrinjavanjem i druge probleme (Mesić i Bagić, 2011; Šućur, 2009) te je gotovo nevjerojatno da bi se u takvim nepovoljnim uvjetima dogodio visoki rast stopa fertiliteta. Blagi porast broja rođenih srpske nacionalnosti može se bolje objasniti činjenicom da je poboljšavanjem odnosa prema nacionalnim manjinama $u$ RH došlo do smanjenja etnomimikrije, tj. prikrivanja vlastite narodnosti deklariranjem pripadnosti većinskom narodu. Da je etnomimikrija bila prisutna, potvrđuju i pozivi srpskih dužnosnika pripadnicima srpske manjine u RH da se na popisu stanovništva izjasne kao Srbi (Jović, 2011). Poboljšanjem statusa srpske nacionalne manjine povećava se i broj majki koje stvarno žive u RH i koje se počinju deklarirati kao pripadnice srpske narodnosti, što dovodi do povećanja broja rođenja koja se pripisuju srpskim majkama. Uzevši u obzir sve navedeno, čini se da je povećanje stopa fertiliteta srpske etničke skupine rezultat smanjenja broja popisanih fertilnih žena i povećanja broja prijavljenih rođenja srpskih majki, a ne stvarne promjene fertiliteta $u$ toj etničkoj skupini.

Slična situacija visokog rasta fertiliteta događa se i u bošnjačkoj zajednici, s razlikom da kod njih broj popisanih žena između 2001. i 2011. raste. To se čini proturječim tezi o smanjenju broja popisanih zbog strožih uvjeta dolazaka u RH (jednom tjedno) za skupine koje graniče s RH. No za razliku od srpske nacionalne manjine broj pripadnika bošnjačke etničke skupine ne smanjuje se, upravo zbog povećanja deklariranja Bošnjakom muslimanske populacije koja živi u RH. Naime stanovništvo muslimanske vjeroispovijesti s područja Bosne i Hercegovine u drugoj polovini 20. stoljeća nacionalno se deklariralo Muslimanima. Tek je 1993. u Bosni i Hercegovini uvedena narodnost »Bošnjak « za pripadnike muslimanske vjeroispovijesti koji žive u Bosni i Hercegovine ili su podrijetlom iz nje. Pripadnici političke i vjerske elite u BiH nastojali su postići da se etnički Muslimani počnu deklarirati kao etnički Bošnjaci (Jović, 2011), a to su činili i predstavnici bošnjačke nacionalne manjine u drugim zemljama (Dimitrovova, 2001), pa tako i u RH. To je izazvalo pomutnju i razdore $u$ etničkom korpusu muslimanske populacije, ne samo u BiH nego i u susjednim zemljama, koja je vidljiva i u kodiranju narodnosti u obrascima DEM-1 u RH, gdje su od 1998. do 2000. oznake narodnosti za »bivše « Muslimane bile »Musliman «, »Bošnjak « i »Musliman-Bošnjak«. Od 2001. postoje samo kategorije »Musliman«i »Bošnjak«. Tijekom prvoga desetljeća 21. stoljeća čini se da se sve više pripadnika muslimanske zajednice identificira s bošnjačkom narodnošću. 
Iz svega toga proizlazi da se broj popisanih fertilnih žena, ali i broj rođenih Bošnjaka povećavao tijekom istraživanog razdoblja i da su stope fertiliteta rasle jer je broj djece bošnjačkih majki rastao brže od broja popisanih bošnjačkih žena. Na rast broja rođenih Bošnjaka vjerojatno je utjecao i pad etnomimikrije, koja je vjerojatno bila izazvana nepovoljnim stavovima o bošnjačkoj populaciji nakon hrvatsko-bošnjačkog sukoba u BiH. Nažalost, nije bilo moguće analizirati stope fertiliteta onih koji se deklariraju Muslimanima, jer u je statistikama o broju žena prema dobi i narodnosti iz popisa 2001. i 2011. narodnost »Musliman« pribrojena kategoriji »Ostali«.

Za razliku od srpske i bošnjačke populacije albanska i romska bilježe, barem nominalno, pad fertiliteta. Trend fertiliteta tih dviju skupina u ovom istraživanju smatra se jedinim pouzdanim s obzirom na dosad istaknute metodološke poteškoće. Naime budući da albanska i romska populacija nemaju matičnu državu koja graniči s RH, na njih se ne odnosi teza o smanjenju broja pripadnika zbog razlika u metodologiji popisa. Rast njihove populacije ne može se tako jasno pripisati ni promjenama u etničkom identitetu (poput Bošnjaka) ili etnomimikriji. Identitet tih dviju skupina relativno je čvrst, a zbog različitog jezika i imena, a u slučaju Roma često i izgleda, vrlo je teško prikazati se pripadnikom većinskog naroda. Uz ogradu o nepoznavanju dinamike migracija tih dviju etničkih skupina, njihov povećani broj u istraživanom razdoblju vjerojatno je rezultat visokog fertiliteta.

Iako broj rođenih Roma i Albanaca raste, vidljivo je smanjenje brzine rađanja, tj. godišnjih stopa fertiliteta. To se s obzirom na društveno-ekonomski razvoj čini očekivanim. Naime obje skupine imale su visoki fertilitet zbog svoje zatvorenosti i kulturne različitosti, Romi dodatno i zbog izuzetno lošeg ekonomskog statusa. Albanci imaju visoki fertilitet i u matičnim područjima Kosova (Brunborg, 2002) i Makedonije (Brunnbauer, 2004), uzrokovan tradicionalnom ulogom žena i kulturnim posebitostima svoje populacije. Romi su se donedavno nalazili u uvjetima prije demografske tranzicije, koju su karakterizirali visoki fertilitet i mortalitet dojenčadi i djece, rast populacije i izrazito loš ekonomski status. U Hrvatskoj su obje skupine bile endogamne i kulturno odvojene od ostatka populacije, što je podržavalo njihove visoke stope fertiliteta. No tijekom prvoga desetljeća 21. stoljeća dolazi do promjene društveno-ekonomskih odnosa, ali i u percepciji ljudskih prava (posebice ženskih) i rodnih uloga. Povećava se i briga za manjinska prava. Tematiziranje tih promjena izlazi iz okvira ove rasprave, no bitno je naglasiti da je »Nacionalnom populacijskom politikom « iz 2006., između ostalog, predviđeno poticanje obrazovanja, zapošljivosti i prava mladih žena, jednakosti spolova i aktivne uloge oca u odgoju djeteta, 
smanjenja diskriminacije prema ženama i niz drugih mjera čiji je cilj učiniti žene aktivnim sudionicama u društvenom i ekonomskom životu. Ta je politika odraz i ekonomskih promjena koje su se događale u prvom desetljeću 21. stoljeća, u kojemu raste potreba za educiranom radnom snagom. Sve te promjene sigurno su zahvatile i albansku i romsku populaciju, tako da se rastaču tradicionalne predodžbe o braku i roditeljstvu. To je posebice vidljivo u romskoj populaciji, gdje se ulažu i velika materijalna sredstva ne bi li se popravio zdravstveni, ekonomski, obrazovni i drugi status prije svega žena. Prema Izvješću za provedbu akcijskog plana desetljeća za uključivanje Roma za 2009. i 2010. godinu (Ured za nacionalne manjine..., 2011), u te dvije godine za »Projekt podrške Romima« utrošeno je 21.595.932,89 kuna, od čega 5.748.267,26 iz državnog proračuna, a za legalizaciju romskih naselja osiguran je iznos od 9,2 milijuna kuna. Da su za promjenu fertiliteta nužne promjena uloge žene i njezina ekonomska emancipacija, pokazuje istraživanje iz Srbije koje nije utvrdilo razlike $u$ fertilitetu između bogatih i siromašnih Roma, gdje je bogatstvo vjerojatno bilo rezultat muškarčeve ekonomske aktivnosti, a ne ženine (Čvorović, 2004). Pad fertiliteta Roma u RH potvrđuje i istraživanje Roma u selu Kuršanec u Međimurskoj županiji (Šlezak, 2010).

Zanimljivu dinamiku promjene fertiliteta pokazuje i hrvatska etnička skupina. Broj Hrvata između dva popisa pada, što zbog negativnoga prirodnoga kretanja, što zbog promjene popisne metodologije, koja je zahvatila hrvatsku populaciju koja uobičajeno živi u susjednim zemljama. No dinamika fertiliteta $\mathrm{u}$ velikom je dijelu određena dinamikom rađanja djece hrvatske narodnosti. Taj broj doživio je pad početkom prvoga desetljeća 21. stoljeća, da bi se sredinom desetljeća oporavio, no nije se vratio na prijašnje razine. Prema raspoloživim podacima, broj rođenih u promatranom razdoblju lagano pada, a stope fertiliteta malo rastu. No jednostavni linearni model trenda ne objašnjava dobro dinamiku fertiliteta. Nije jasno zašto se dogodio pad fertiliteta i broja rođenih početkom tog desetljeća i je li taj pad pokazatelj nekog stvarnog procesa ili samo nasumična fluktuacija. Promatrano je razdoblje prekratko da bi se zaključilo o prirodi te promjene, a slučajni usponi i padovi vrlo su karakteristični za kretanje vremenski uređenih podataka. Da bi se dobila prava informacija o trendu fertiliteta hrvatske narodnosti, potrebni su duže razdoblje i tehnike analize vremenskih nizova, no i ti podaci mogu biti nepouzdani zbog različitih načina popisivanja stanovništva. Stoga se o dinamici fertiliteta hrvatske narodnosti ne može donijeti konačan i nedvosmislen zaključak.

Kod Čeha, Mađara, Slovenaca, Talijana i ostalih vidljiv je manje ili više izražen rast stopa fertiliteta, a isto tako i smanjenje broja fertilnih žena u 
promatranom razdoblju. Objašnjenje za takvu situaciju u pravilu je slično kao i za srpsku i bošnjačku manjinu, tj. vjerojatno su navedene nacionalne skupine bile prezastupljene u popisu 2001. Ipak, kod Talijana i donekle kod skupine »ostalih « vidljiv je porast broja rođenih, što je moglo povećati stope fertiliteta, no valja imati na umu da je godišnji broj rođenja kod svih navedenih skupina (osim »ostalih «) stotinu ili manji i da je kod tako malog broja rođenih vrlo teško zaključivati o promjenama u društvenim procesima koje bi objasnile promjene u fertilitetu. Usto, kod skupine »ostali« iz popisa 2001. bilo je oko 90.000 onih koji se nisu izjasnili o nacionalnoj pripadnosti, dok je taj broj 2011. bio svega oko 27.000. Budući da se broj pripadnika nacionalnih manjina u RH do 2011. smanjio, nije vjerojatno da su se "neopredijeljeni« opredijelili za neku etničku skupinu, nego je vjerojatnije da se 2011. uopće nisu popisali jer su, kao i opredijeljeni pripadnici nacionalnih manjina, živjeli u nekoj od susjednih zemalja. Stoga i njihova stopa fertiliteta raste.

Drugi cilj ovog istraživanja bio je objasniti razlike u stopama fertiliteta između hrvatskog naroda i nacionalnih manjina 2011. Vidljivo je da je hrvatska opća stopa fertiliteta viša od bošnjačke, češke, mađarske, slovenske, srpske i talijanske, a manja od albanske, romske i ostalih. Tamo gdje je hrvatska opća stopa fertiliteta viša razlike nisu toliko velike i uglavnom su rezultat razlika u dobno specifičnim stopama fertiliteta. Najveća je razlika u općim stopama fertiliteta između hrvatske i slovenske narodnosti $(19,14)$ i tu udio razlike u dobnim strukturama pokazuje najveću važnost (oko 41\%). Uvidom $\mathrm{u}$ dobnu strukturu slovenskoga fertilnoga kontingenta vidljiva je veća zastupljenost starijih fertilnih skupina. Kada je hrvatska opća stopa fertiliteta niža, najveća je razlika između hrvatske i romske skupine, i opet najvećim dijelom zbog izuzetno visokih dobno specifičnih stopa fertiliteta Roma.

Osim ekonomskih, društvenih i kulturnih na niži fertilitet nacionalnih manjina utječu i drugi čimbenici poput geografske izoliranosti, nemogućnosti nalaženja bračnog partnera, sukoba vrijednosti mladih i njihovih roditelja, izloženosti medijima i dr. (Forste i Tienda, 1996). Već je navedeno da neke etničke skupine imaju nepovoljan ekonomski i društveni položaj (Mesić i Bagić, 2011; Šućur, 2009). Također, prostorna i brojčana ograničenost manjinskih populacija u Hrvatskoj i time uvjetovana obrazovna i radna struktura njihova stanovništva vjerojatno dodatno utječu na smanjenje stopa fertiliteta. U uvjetima prostorne ograničenosti i povećanog udjela ruralnog stanovništva izgledne su i poteškoće pri nalaženju bračnog partnera i stupanju u brak. No bilo bi netočno svim manjinskim skupinama s nižim 
fertilitetom pripisati lošiji socioekonomski status. Iz prethodnog istraživanja vidljivo je da majke talijanske narodnosti imaju višu zaposlenost i bolju obrazovnu strukturu od majki drugih narodnosti (Pavić, 2013).

Važan čimbenik pri objašnjenju razlika u fertilitetu etničkih skupina svakako je kulturna i društvena kohezija i percepcija vlastite etničke zajednice kao posebne i odvojene od ostalih. Etnička kohezija pomaže ublaživanju negativnih ekonomskih i društvenih procesa koji zahvaćaju nacionalnu manjinu, to više što je manjina kulturno, vjerski i jezično drugačija od većinskog naroda. Stoga ne čude visoke stope fertiliteta romske i albanske etničke skupine. Dokaz etničke kohezije i percepcije posebnosti jest i odabir partnera prema etničkoj skupini. Albanke i Romkinje u većini slučajeva biraju partnere iste narodnosti, dok je kod češke, mađarske, slovenske, a napose talijanske narodnosti etnička homogenost partnera znatno niža (Pavić, 2013). U tim slučajevima prostorna segregacija i manja veličina skupine otežavaju nalaženje partnera iz većinskog naroda (Smits, 2010), a samim tim i snižavaju stope fertiliteta. U slučajevima niske etničke homogenosti partnera postavlja se pitanje o opravdanosti analize fertiliteta na temelju narodnosti žena. Ako ženin partner dolazi iz većinske etničke skupine (a najčešće je tako), vrlo je teško razlučiti utječu li na fertilitet jače »manjinski«ili »većinski« čimbenici i percipira li žena sebe članicom manjinske skupine ili većinskog naroda. Stoga u tim slučajevima analiza fertiliteta etničkih skupina ima manju praktičnu vrijednost, posebice pri kreiranju politika prema etničkim skupinama.

Rezultate ovog istraživanja treba oprezno interpretirati. Kretanje broja žena pojedinih narodnosti u istraživanom razdoblju procijenjeno je linearnim modelom, koji pojednostavljuje godišnje promjene broja stanovnika. To je bilo nužno zbog nemogućnosti procjene migracije fertilnih kontingenata etničkih skupina. Kratkoročne migracijske promjene mogu naglo promijeniti broj fertilnih žena, a samim tim i godišnje stope fertiliteta, što je posebice akutan problem u uvjetima ekonomske krize, kada se može očekivati iseljavanje mlađeg stanovništva. Stoga analizu promjene stopa fertiliteta $u$ istraživanom razdoblju valja interpretirati kao postojanje ili nepostojanje općeg trenda, bez prevelikog oslanjanja na promjene godišnjih stopa. Isto tako, razlika između stopa fertiliteta pojedinih etničkih skupina nije uvijek pouzdana zbog relativno maloga godišnjeg broja rođenja. $S$ tim je povezana i već spomenuta praktična vrijednost analize tamo gdje je broj rođenja malen, a etnička homogenost u izboru partnera niska. Zaključno, ovo je istraživanje pokazalo da je povećanje stopa fertiliteta kod određenih etničkih skupina ponajprije rezultat metodoloških razlika u popisima stanovništva 
2011. i 2011. Pad stopa fertiliteta kod albanske i romske populacije rezultat je modernizacijskih procesa, veće senzibilnosti prema nacionalnim manjinama i većih političkih i materijalnih napora da se poboljša socioekonomski status pripadnika nacionalnih manjina, posebice žena. Suvremene razlike u stopama fertiliteta između većinskog naroda i nacionalnih manjina najvidljivije su upravo kod albanske i romske narodnosti zbog složenog odnosa socioekonomskih i kulturnih čimbenika koji uvjetuju učestalost rađanja. Tamo gdje su stope fertiliteta nacionalnih manjina niže od stopa većinskog naroda razlike u stopama nisu toliko izražene i vjerojatno su odraz nešto lošijih socioekonomskih uvjeta u kojima pripadnici tih manjina žive. Ipak, uzevši u obzir rezultate prošlog istraživanja (Pavić, 2013), kod tih se manjina sama pripadnost etničkoj skupini ne čini snažnim čimbenikom objašnjenja razlika u fertilitetu, posebice takvih da bi postojala potreba za sveobuhvatnom etnički diferenciranom populacijskom politikom.

\section{LITERATURA}

Akrap, A. (2008). Demografski kontekst raspada SFR Jugoslavije, PILAR - časopis za društvene i humanističke studije, 3 (5): 11-58.

Brunborg, H. (2002). Report on the Size and Ethnic Composition of the Population of Kosovo, http://www.icty.org/x/file/About/OTP/War_Demographics/en/milosevic_ kosovo_020814.pdf (29. 12. 2013.).

Brunnbauer, U. (2004). Fertility, families and ethnic conflict: Macedonians and Albanians in the Republic of Macedonia, 1944 - 2002, Nationalities Papers, 32 (3): 565-598.

Coleman, D. A. i Dubuc, S. (2010). The fertility of ethnic minorities in the UK, 1960s 2006, Population Studies, 64 (1): 19-41, doi: 10.1080/00324720903391201.

Čičak-Chand, R. (1999). Islam i muslimani u Hrvatskoj: skica stvaranja muslimanskog/ bošnjačkog sociokulturnog prostora, Migracijske i etničke teme, 15 (4): 451-464.

Čvorović, J. (2004). Reproductive behavior, ethnicity and socio-economic status: a comparison of two Serbian Gypsy groups, Гласник Етнографског института CAHY, 52: 147-153.

Dimitrovova, B. (2001). Bosniak or Muslim? Dilemma of one Nation with two Names, Southeast European Politics, 2 (2): 94-108.

Forste, R. i Tienda, M. (1996). What's behind racial and ethnic fertility differentials?, Population and Development Review, 22 (supplement): 109-133.

Hrvatić, N. (2004). Romi u Hrvatskoj: od migracija do interkulturalnih odnosa, Migracijske i etničke teme, 20 (4): 367-385.

Jović, D. (2011). Bitka za etnički status u postjugoslavenskim državama, Političke analize, 5: 36-45.

Klemenčič, M. (2006). The Effects of the Dissolution of Yugoslavia on Minority Rights: the Italian Minority in Post-Yugoslav Slovenia and Croatia, u: S. G. Ellis, G. Hálfdanarson i A. K. Isaacs (ur.). Citizenship in historical perspective. Pisa: Edizioni Plus - Pisa University Press, 333-347. 
Koytcheva, E. i Philipov, D. (2008). Bulgaria: Ethnic differentials in rapidly declining fertility, Demographic Research, 19: 361-402, doi: 10.4054/DemRes.2008.19.13.

Mesić, M. i Bagić, D. (2011). Manjinski povratak u Hrvatsku: studija otvorenog procesa. Zagreb: UNHCR.

Pavić, D. (2013). Natalitet etničkih skupina u Hrvatskoj od 1998. do 2008., Migracijske i etničke teme, 29 (1): 39-62, doi: 10.11567/met.29.1.2.

Penn, R. i Lambert, P. (2002). Attitudes towards ideal family size of different ethnic/ nationality groups in Great Britain, France and Germany, Population Trends, (108): $49-58$.

Pepeonik, Z. (1967). Česi u Hrvatskoj: prilog poznavanju kolonizacije dijela Savskodravskog međurječja, Geografski glasnik, 29 (1): 43-59.

Preston, S. H., Heuveline, P. i Guillot, M. (2003). Demography: Measuring and Modeling Population Processes. Oxford: Blackwell Publishers.

Raduški, N. (2003). Etnička slika Srbije - popis 2002. godine, Migracijske i etničke teme, 19 (2-3): 253-267.

Smits, J. (2010). Ethnic Intermarriage and Social Cohesion. What Can We Learn from Yugoslavia?, Social Indicators Research, 96 (3): 417-432, doi: 10.1007/s11205-009-9485-y.

Šlezak, H. (2009). Prostorna segregacija romskog stanovništva u Međimurskoj županiji, Hrvatski geografski glasnik, 71 (2): 65-81.

Šlezak, H. (2010). Prirodno kretanje romskog stanovništva u Međimurskoj županiji slučaj romskog naselja Kuršanec, Hrvatski geografski glasnik, 72 (2): 77-99.

Šućur, Z. (2009). Pokazatelji ekonomske isključenosti među Hrvatima i nacionalnim manjinama u Republici Hrvatskoj, Revija za socijalnu politiku, 16 (2): 115-140, doi: 10.3935/rsp.v16i2.837.

Ured za nacionalne manjine Vlade Republike Hrvatske (2011). Izvješće o provođenju akcijskog plana desetljeća za uključivanje Roma za 2009. i 2010. godinu, http://www. uljppnm.vlada.hr/images/pdf/izvjesce_o_provodjenju_akcijskog_plana.pdf. (04. 03. 2014.).

Yang, Y. i Morgan, S. P. (2010). How big are educational and racial fertility differentials in the U.S.?, Social Biology, 50 (3-4): 167-187.

Živić, D. i Pokos, N. (2004). Demografski gubitci tijekom Domovinskog rata kao odrednica depopulacije Hrvatske (1991. - 2001.), Društvena istraživanja, 13 (4-5): 727 750.

Živić, D. (2008). Demografske prilike u Hrvatskoj početkom 1990-ih godina, Časopis za suvremenu povijest, 40 (1): 219-236. 


\section{Fertility Dynamics of Ethnic Groups in Croatia from 1998 to 2012}

\section{Dario Pavić}

\section{SUMMARY}

Fertility dynamics of minority ethnic groups in some countries may differ from that of the majority group, depending on their economic, social and cultural status. This study aimed to assess the change in the general fertility rate and total fertility rate of ethnic groups in the Republic of Croatia from 1998 to 2012. The number of fertile women in the analyzed period was estimated by linear model, based on their number in the years 2001 and 2011, and birth data for each year were available from the form DEM-1. The second objective was to compare differences in general fertility rates of ethnic groups in the 2011. For this analysis the standardization of the fertility rate was performed, the population of Croatian ethnicity being the standard. Also, the decomposition of the differences between the general fertility rate of Croats and ethnic minorities was performed, and the components were age-specific fertility rates and age structure. The analysis of time trends in fertility rates showed that the increase in fertility rates is most likely the result of different ways of enumeration of the population in 2001 and 2011, while the real trend of decline in fertility observed in Roma and Albanian ethnicity is due to the change in traditional role of women and the general improvement of the status of women in these populations. Contemporary differences in fertility of ethnic groups are mainly the result of differences in the age-specific fertility rates of ethnic groups, rather than differences in the age structure of fertile contingents. The absolute differences in general fertility rates between ethnic groups are not excessive and are the result of physical, economic and social isolation of ethnic minorities.

KEY WORDS: ethnicity, fertility, births, Croatia, Census 